\title{
Plasma interferon-alpha is associated with double-positivity for autoantibodies but is not a predictor of remission in early rheumatoid arthritis - a spin-off study of the NORD-STAR randomized clinical trial
}

\author{
Marit Stockfelt ${ }^{1,2^{*}}$ (D, Anna-Carin Lundell ${ }^{1}$, Merete Lund Hetland ${ }^{3,4}$, Mikkel Østergaard ${ }^{3,4}$, Till Uhlig ${ }^{5}$,
} Marte Schrumpf Heiberg ${ }^{5}$, Espen A. Haavardsholm ${ }^{5,6}$, Michael T. Nurmohamed ${ }^{7,8}$, Jon Lampa ${ }^{9}$, Dan Nordström ${ }^{10}$, Kim Hørslev Petersen ${ }^{11,12}$, Bjorn Gudbjornsson ${ }^{13,14}$, Gerdur Gröndal ${ }^{13,14}$, Jonathan Aldridge ${ }^{1}$, Kerstin Andersson ${ }^{1}$, Kaj Blennow ${ }^{15,16}$, Henrik Zetterberg ${ }^{15,16,17,18}$, Ronald van Vollenhoven ${ }^{8,9}$ and Anna Rudin 1,2

\begin{abstract}
Background: The type I interferon (IFN) gene signature is present in a subgroup of patients with early rheumatoid arthritis (RA). Protein levels of IFNa have not been measured in RA and it is unknown whether they associate with clinical characteristics or treatment effect.

Methods: Patients with early untreated RA ( $n=347$ ) were randomized to methotrexate combined with prednisone, certolizumab-pegol, abatacept, or tocilizumab. Plasma IFNa protein levels were determined by single molecular array (Simoa) before and 24 weeks after treatment initiation and were related to demographic and clinical factors including clinical disease activity index, disease activity score in 28 joints, swollen and tender joint counts, and patient global assessment.

Results: IFNa protein positivity was found in $26 \%$ of the patients, and of these, $92 \%$ were double-positive for rheumatoid factor (RF) and anti-citrullinated protein antibodies (ACPA). IFNa protein levels were reduced 24 weeks after treatment initiation, and the absolute change was similar irrespective of treatment. IFNa protein positivity was associated neither with disease activity nor with achievement of CDAl remission 24 weeks after randomization.
\end{abstract}

\footnotetext{
* Correspondence: marit.stockfelt@gu.se

'Department of Rheumatology and Inflammation Research, Institute of Medicine, Sahlgrenska Academy at the University of Gothenburg,

Guldhedsgatan 10A, S-405 30 Gothenburg, Sweden

${ }^{2}$ Rheumatology Clinic, Sahlgrenska University Hospital, Gothenburg, Sweden

Full list of author information is available at the end of the article
}

C C The Author(s). 2021 Open Access This article is licensed under a Creative Commons Attribution 4.0 International License, which permits use, sharing, adaptation, distribution and reproduction in any medium or format, as long as you give appropriate credit to the original author(s) and the source, provide a link to the Creative Commons licence, and indicate if changes were made. The images or other third party material in this article are included in the article's Creative Commons licence, unless indicated otherwise in a credit line to the material. If material is not included in the article's Creative Commons licence and your intended use is not permitted by statutory regulation or exceeds the permitted use, you will need to obtain permission directly from the copyright holder. To view a copy of this licence, visit http://creativecommons.org/licenses/by/4.0/ The Creative Commons Public Domain Dedication waiver (http://creativecommons.org/publicdomain/zero/1.0/) applies to the data made available in this article, unless otherwise stated in a credit line to the data. 
Conclusion: IFNa protein positivity is present in a subgroup of patients with early RA and associates with doublepositivity for autoantibodies but not with disease activity. Pre-treatment IFNa positivity did not predict remission in any of the treatment arms, suggesting that the IFNa system is distinct from the pathways of TNF, IL-6, and T-cell activation in early RA.

A spin-off study of the NORD-STAR randomized clinical trial, NCT01491815 (ClinicalTrials), registered 12/08/2011, https://clinicaltrials.gov/ct2/show/NCT01491815.

\section{Introduction}

Rheumatoid arthritis (RA) is a chronic disease characterized by joint inflammation, which if untreated may lead to progressive bone destruction. Genetic and environmental factors contribute to the predisposition towards disease development, including smoking and genes of the type I interferon (IFN) pathway [1-3]. The majority of patients with RA have autoantibodies against the Fc portion of IgG (rheumatoid factor (RF)) and/or citrullinated peptides (ACPA). Two studies have shown that ACPA positivity is associated with elevated expression of type I IFN responsive genes (IRG) in RA [4, 5], while others have reported that these factors are unrelated $[6$, 7]. Whether RF or ACPA are associated with IFN $\alpha$ protein is unknown.

The majority of IFN $\alpha$ is produced by plasmacytoid dendritic cells following their recognition of microbial nucleic acids and immune complexes. Binding to the type I IFN receptor leads to upregulation of genes involved in immune processes including restriction of viral replication and enhancement of B cell responses [8]. A persistent upregulation of IRG, the type I IFN signature, is evident in several autoimmune diseases including systemic lupus erythematosus (SLE) and RA [9]. In RA, the expression of IRG is upregulated in peripheral blood compared to controls [10] and was suggested to associate with disease activity [11] and predict treatment response to tumor necrosis factor inhibitors (TNFi) [1214], interleukin-6 receptor inhibitors (IL-6Ri) [15], and B-cell depletion therapy [16-19]. However, the stimulation of IRG expression is not specific for IFN $\alpha$ and which genes to include is not standardized. Since functional bioassays are not specific for IFN $\alpha$, and traditional ELISAs are insufficiently sensitive, a reliable method to measure IFN $\alpha$ protein has been lacking. Recently, a digital ELISA based on single molecular array (Simoa) was developed that enables direct quantification of IFN $\alpha$ at attomolar levels [20]. In SLE, IFN $\alpha$ protein associated with disease activity and predicted the duration of remission [21], but protein levels of IFNa have previously neither been reliably measured in RA nor related to clinical characteristics or treatment effect.

Early and effective medical treatment improves wellbeing and prognosis in RA. Current European and US guidelines advocate initiating treatment with methotrexate (MTX) or other conventional synthetic diseasemodifying anti-rheumatic drug (DMARD) [22, 23]. If the therapeutic effect is insufficient, another conventional, biologic, or targeted synthetic DMARD may be added. In the NORD-STAR cohort, active conventional treatment and biologic treatment with certolizumab-pegol, abatacept, and tocilizumab were compared head-to-head [24]. All four treatments achieved high remission rates on a group level. At the individual level, it may be possible to predict treatment effect using biomarkers, but specific biomarkers that inform on the effect of different treatment strategies in early RA are lacking.

We used plasma samples from the Swedish patients in the NORD-STAR cohort to explore whether IFN $\alpha$ protein positivity is present in patients with early untreated $\mathrm{RA}$, whether levels of IFN $\alpha$ change after treatment with conventional and biologic treatment strategies, and whether baseline IFN $\alpha$ protein levels predict remission at week 24 .

\section{Materials and methods}

\section{Study population}

The study population consisted of 347 Swedish patients included in the NORD-STAR trial, a multinational phase four, investigator-initiated, randomized observer-blinded clinical trial of 812 patients with early untreated RA [24]. All patients fulfilled the American College of Rheumatology (ACR) and European League Against Rheumatism (EULAR) 2010 criteria. Patients were assessed for eligibility during 2012-2018. All patients were of age 18 or above, had a symptom duration of fewer than 24 months, and at least two (of 66) swollen and two (of 68) tender joints. All patients had to be RF and/or ACPA positive or have a C-reactive protein (CRP) of at least $10 \mathrm{mg} / \mathrm{L}$. All patients had moderate to severe disease activity score (DAS28-CRP $\geq 3.2$ ) and all were DMARD naïve. Active infection or any major episode of infection requiring hospitalization within 4 weeks of screening constituted exclusion criteria. All participants signed a written informed consent and the study was approved by the regional ethics board in Stockholm (d.nr. 2011/2069-31/4 and amendment 2019-05705). 


\section{Intervention}

Details of the study protocol and data regarding clinical outcome at week 24 in the full NORD-STAR cohort are published [24, 25]. In brief, Swedish patients were randomized 1:1:1:1 stratified by ACPA and sex to MTX escalated to $25 \mathrm{mg} /$ week with folic acid supplementation combined with one of the following: arm 1, active conventional treatment (oral prednisone tapered from 20 to $5 \mathrm{mg} /$ day in 9 weeks); arm 2, TNFi (certolizumab-pegol, $200 \mathrm{mg}$ subcutaneously every other week, loading dose $400 \mathrm{mg}$ at weeks 0,2 , and 4); arm 3, cytotoxic Tlymphocyte-associated molecule-4 immunoglobulin (CTLA-4Ig, abatacept, $125 \mathrm{mg}$ subcutaneously every week); or arm 4, IL-6Ri (tocilizumab, $8 \mathrm{mg} / \mathrm{kg}$ intravenously every 4 weeks or $162 \mathrm{mg}$ subcutaneously every week). There was no difference between the intentionto-treat and the per-protocol treatment arm. Oral steroids were not allowed for patients who received a biological DMARD (arm 2-4). Intra-articular corticosteroid injections were allowed on demand up to week 20 in arm 1 and until week 12 in arm 2-4. If an oral dose of $25 \mathrm{mg} /$ week MTX was not tolerated, the dose was reduced or changed to subcutaneously administered MTX; if MTX was still not tolerated, it was replaced with leflunomide or azathioprine, or monotherapy for patients on biologic medication. None of the patients was treated with hydroxychloroquine.

\section{Clinical evaluation}

The primary clinical endpoint was remission according to the clinical disease activity index $($ CDAI $\leq 2.8)$ at week 24. In addition, disease activity was evaluated on day 1 before the start of treatment and 24 weeks after treatment initiation with the following parameters: CRP, erythrocyte sedimentation rate (ESR), DAS28-ESR and DAS28-CRP, swollen joint count in 66 joints (SJC66), tender joint count in 68 joints (TJC68), and patient global assessment (PGA). Positivity for ACPA and RF was determined according to cut-off levels at the local laboratories.

\section{Quantification of IFNa in plasma}

Plasma was kept frozen until analysis. Plasma IFN $\alpha$ protein concentration was measured with Simoa on an HD1 Analyzer (Quanterix, Billerica, MA). The analysis was performed blinded to patient characteristics. The Simoa assay contained an inhibitor for RF and heterophilic antibodies in order to prevent false-positive results. Values below the detection limit were assigned the lowest limit of detection (LLOD, $70 \mathrm{fg} / \mathrm{mL}$ ). Within-run and between-run coefficients of variation (CVs) for the Simoa assay were $9.8 \%$ and $7.3 \%$ at $1.9 \mathrm{pg} / \mathrm{mL}$ and $8.1 \%$ and $7.3 \%$ at $10.6 \mathrm{pg} / \mathrm{mL}$. The assay was not controlled for concentrations lower than $1.9 \mathrm{pg} / \mathrm{mL}$. IFN $\alpha$ protein positivity was defined as an IFN $\alpha$ level $\geq 136 \mathrm{fg} / \mathrm{mL}$, based on three standard deviations above mean level for healthy blood donors, measured using the same method [21]. IFN $\alpha$ protein levels could not be obtained due to a technical error in one sample collected at baseline and one sample collected at 24 weeks.

\section{Statistics}

Mann-Whitney U-test, Wilcoxon matched-pairs signed rank test, Kruskal-Wallis test followed by Dunn's multiple comparison test (GraphPad Prism software v9.02, La Jolla, CA), and Fisher's exact test (IBM SPSS Statistics v27, Armonk, NY) were used as described in the respective figure legends. For analysis of autoantibody status in relation to IFN $\alpha$, after Fisher's exact test, a post hoc step-down Bonferroni-Holm correction for multiple testing was performed. Multivariable logistic regression was used to identify factors independently associated with IFN $\alpha$ protein positivity and identify whether IFN $\alpha$ protein positivity was independently associated with remission at week 24 (GraphPad Prism software). A p-value of $<0.05$ was considered statistically significant $\left({ }^{*} \mathrm{P}<0.05\right.$, ${ }^{* *} \mathrm{P}<0.01,{ }^{* * *} P<0.001$, and $\left.{ }^{* * * *} P<0.0001\right)$.

\section{Results}

IFNa protein positivity is present in a subgroup of untreated early RA patients

Baseline demographic and clinical characteristics of the 347 patients with untreated early RA in each treatment arm are shown in Table 1 . There were no significant differences in baseline characteristics between the four treatment arms. Of the 346 patients with data for plasma IFN $\alpha$ protein levels at baseline, $26 \%(n=91)$ were IFN $\alpha$ positive, with similar proportions in the four treatment arms, i.e., methotrexate in combination with either prednisone (27\%, $\mathrm{n}=23)$, TNFi $(22 \%, \mathrm{n}=19)$, CTLA-4Ig (29\%, n = 27), or IL-6Ri (27\%, n = 22) (Fig. 1).

\section{IFNa protein positivity is associated with double- positivity for RF and ACPA}

To determine the demographic and clinical characteristics of the IFN $\alpha$ protein-positive subgroup, we compared patients who were positive or negative for IFN $\alpha$ protein at baseline. IFN $\alpha$ protein positivity was associated with double-positivity for RF and ACPA, and of IFN $\alpha$ positive patients, 92\% were double-positive for RF and ACPA compared to $57 \%$ of IFN $\alpha$-negative patients. In contrast, only $3 \%$ of IFN $\alpha$-positive patients were doublenegative, and only $4 \%$ were positive for either RF or ACPA compared to $13 \%$ and $29 \%$ of IFN $\alpha$-negative patients, respectively (Table 2 and Additional Figure 1). Baseline IFN $\alpha$ protein positivity was not associated with age, sex, or BMI, and not with disease activity measures at baseline or 24 weeks after treatment initiation. Similar 
Table 1 Baseline characteristics of untreated patients with early RA in the four treatment arms

\begin{tabular}{|c|c|c|c|c|c|}
\hline $\mathrm{N}=347$ & MTX + prednisone $(n=85)$ & MTX + TNFi $(n=87)$ & MTX + CTLA-4lg $(n=92)$ & MTX + IL-6Ri $(n=83)$ & P-value \\
\hline Age, years $^{a}$ & $62(21-81)$ & $58(21-79)$ & $58(18-82)$ & $53(25-79)$ & 0.29 \\
\hline Female sex ${ }^{b}$ & $58(68 \%)$ & $58(67 \%)$ & $62(67 \%)$ & $57(69 \%)$ & 0.99 \\
\hline $\mathrm{BMI}, \mathrm{kg} / \mathrm{m}^{2 \mathrm{a}}$ & $26(18-43)$ & $25(19-37)$ & $26(18-38)$ & $25(20-43)$ & 0.11 \\
\hline Current smoker $^{\mathrm{b}}$ & $12(14 \%)$ & $20(23 \%)$ & $18(20 \%)$ & $22(27 \%)$ & 0.22 \\
\hline Autoantibody status & & & & & 0.55 \\
\hline RF-ACPA- ${ }^{b}$ & $11(13 \%)$ & $10(11 \%)$ & $11(12 \%)$ & $4(5 \%)$ & - \\
\hline $\mathrm{RF}+\mathrm{ACPA}-{ }^{\mathrm{b}}$ & $5(6 \%)$ & $6(7 \%)$ & $5(5 \%)$ & $9(11 \%)$ & - \\
\hline RF-ACPA $+^{\mathrm{b}}$ & $11(13 \%)$ & $14(16 \%)$ & $12(13 \%)$ & $17(20 \%)$ & - \\
\hline $\mathrm{RF}+\mathrm{ACPA}+{ }^{\mathrm{b}}$ & $57(67 \%)$ & $57(66 \%)$ & $64(70 \%)$ & $53(64 \%)$ & - \\
\hline Symptom duration, days ${ }^{a, c}$ & $142(25-813)$ & $144(41-702)$ & $170(37-731)$ & $170(37-691)$ & 0.29 \\
\hline $\mathrm{CDAl}^{\mathrm{a}}$ & $30.7(7.8-62.8)$ & $27.9(8.1-68.7)$ & $29.5(14-68.4)$ & $26.8(8.4-55.2)$ & 0.33 \\
\hline DAS28-CRP ${ }^{a}$ & $5.2(2.6-7.7)$ & $5.1(2.2-8.3)$ & $5.1(3.3-7.6)$ & $5.0(2.7-7.3)$ & 0.21 \\
\hline DAS28-ESR ${ }^{\mathrm{a}}$ & $5.6(3.6-8.2)$ & $5.6(2.7-8.7)$ & $5.5(3.7-8.1)$ & $5.3(2.6-7.9)$ & 0.23 \\
\hline SJC- $66^{a}$ & $13(2-42)$ & $12(2-34)$ & $11(2-41)$ & $10(1-27)$ & 0.10 \\
\hline TJC-68 & $15(2-47)$ & $15(1-47)$ & $14(0-62)$ & $13(0-47)$ & 0.55 \\
\hline CRP, $\mathbf{m g} /^{\text {a }}$ & $16(0.5-216)$ & $14(0.5-180)$ & $11(0.3-146)$ & $8.4(0.3-82)$ & 0.19 \\
\hline $\mathrm{ESR}, \mathrm{mm} / \mathrm{h}^{\mathrm{a}}$ & 31 (4-108) & $32(4-98)$ & $28(4-115)$ & $24(2-84)$ & 0.14 \\
\hline PGA, $\mathbf{m m}^{a}$ & $58(2-87)$ & $57(13-100)$ & $61(19-100)$ & $59(9-100)$ & 0.18 \\
\hline
\end{tabular}

Missing data from one patient regarding BMI, RF, IFN day 1, IFN week 24, CDAl week 24, PGA week 24, and ESR week 24 ; from two patients regarding CRP day 1 and DAS28-ESR week 24; from three patients regarding CRP week 24; from four patients regarding CDAI day 1 and DAS28-CRP week 24; and from five patients regarding ESR day 1 and DAS28-ESR day 1

MTX methotrexate, TNFi certolizumab-pegol, CTLA-4Ig abatacept, IL-6Ri tocilizumab, BMI body mass index, RF rheumatoid factor, ACPA anti-citrullinated protein antibodies, CDAl clinical disease activity index, DAS28 disease activity score 28 joints, SJC-66 swollen joint count, 66 joints, TJC-68 tender joint count, 68 joints, CRP C-reactive protein, ESR erythrocyte sedimentation rate, $P G A$ patient global assessment

${ }^{a}$ Median (range), Kruskal-Wallis followed by Dunn's multiple comparison test

${ }^{\mathrm{b}} \mathrm{n}(\%)$, Fisher's exact test

${ }^{\mathrm{C}}$ Retrospective patient-reported joint pain before RA diagnosis

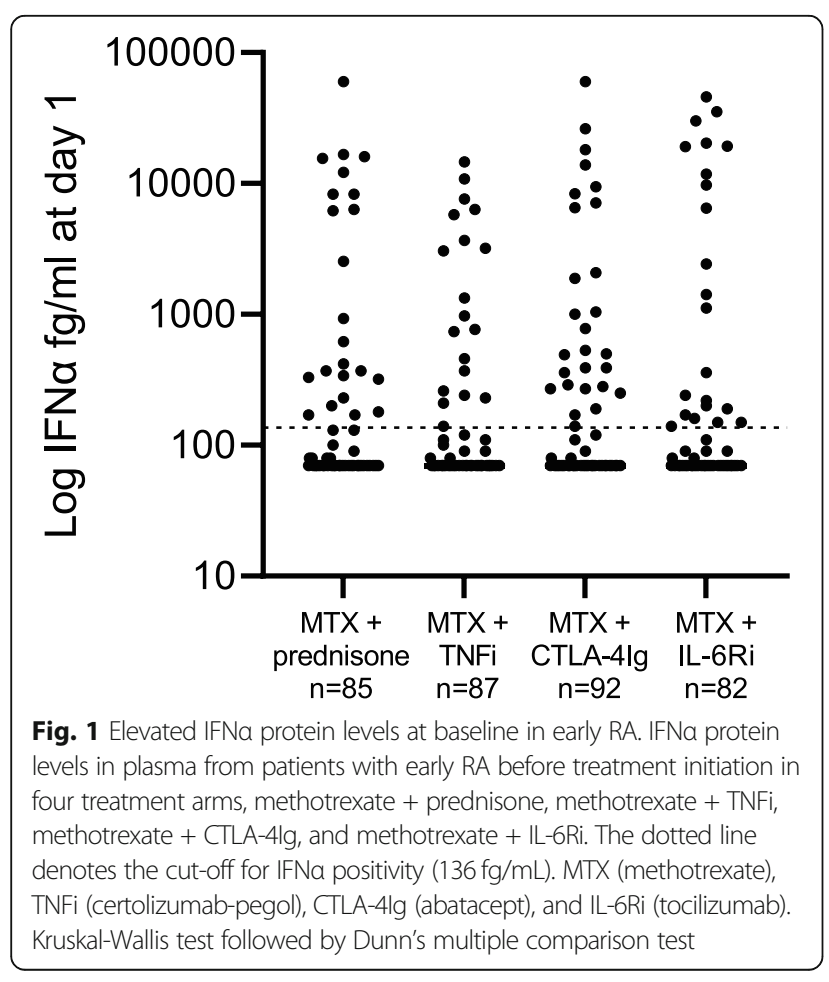

results were obtained when LLOD was used as a cut-off for IFN $\alpha$ positivity (Additional Table 1). When doublepositive patients were divided into IFN $\alpha$-positive and IFN $\alpha$-negative patients, no significant differences in CDAI day 1 or week 24 ( $\mathrm{p}=0.07$ and $\mathrm{p}=0.45$ respectively) or DAS28-ESR day 1 or week $24(\mathrm{p}=0.28$ and $\mathrm{p}=$ 0.79 respectively) were found.

To evaluate whether the association between IFN $\alpha$ and double-positivity for RF and ACPA was due to demographic or clinical characteristics, multivariable logistic regression analysis was performed (Table 3). Double-positivity for RF and ACPA was associated with IFNa protein positivity and increased the odds ratio of IFN $\alpha$ protein positivity ninefold at baseline and fivefold at week 24 when adjusting for current smoking, CDAI, and CRP. Current smoking independently doubled the odds ratio of IFN $\alpha$ protein positivity at week 24 but neither CDAI nor CRP affected the odds ratio. Taken together, baseline IFN $\alpha$ protein positivity was independently associated with double-positivity for RF and ACPA and smoking but not with disease activity in early RA. 
Table 2 Demographic and clinical characteristics of IFNa-positive and IFNa-negative patients

\begin{tabular}{|c|c|c|c|}
\hline$N=346$ & IFNa-negative $(n=255)$ & IFNa-positive $^{a}(n=91)$ & $\mathrm{p}$-value \\
\hline Age, years ${ }^{b}$ & $58(18-81)$ & $58(21-82)$ & 0.53 \\
\hline Female sex ${ }^{c}$ & $170(67 \%)$ & $64(70 \%)$ & 0.60 \\
\hline $\mathrm{BMI}, \mathbf{k g} / \mathrm{m}^{2 \mathrm{~b}}$ & $25(18-43)$ & $26(19-43)$ & 0.22 \\
\hline Current smoker $^{c}$ & $46(18 \%)$ & $25(27 \%)$ & 0.07 \\
\hline Autoantibody status $^{c}$ & & & $<0.0001$ \\
\hline RF-ACPA- & $33(13 \%)$ & $3(3 \%)$ & $\mathrm{p}<0.05^{\mathrm{d}}$ \\
\hline $\mathrm{RF}+\mathrm{ACPA}-$ & $23(9 \%)$ & $2(2 \%)$ & ns \\
\hline RF-ACPA+ & $52(20 \%)$ & $2(2 \%)$ & $\mathrm{p}<0.05^{\mathrm{d}}$ \\
\hline $\mathrm{RF}+\mathrm{ACPA}+$ & $146(57 \%)$ & $84(92 \%)$ & $\mathrm{p}<0.05^{\mathrm{d}}$ \\
\hline \multicolumn{4}{|l|}{ Disease activity day $1^{b}$} \\
\hline CDAl & $27.8(7.8-68.7)$ & $28.6(10.1-68.4)$ & 0.13 \\
\hline DAS28-CRP & $5.1(2.2-8.3)$ & $5.1(3.3-7.7)$ & 0.38 \\
\hline DAS28-ESR & $5.5(2.6-8.7)$ & $5.5(3.3-8.2)$ & 0.43 \\
\hline SJC-66 & $11(1-42)$ & $11(2-38)$ & 0.68 \\
\hline TJC-68 & $13(0-49)$ & $16(2-62)$ & 0.16 \\
\hline CRP, mg/L & $14(0.3-216)$ & $8(0.5-190)$ & 0.16 \\
\hline $\mathrm{ESR}, \mathrm{mm} / \mathrm{h}$ & $28(2-115)$ & $28(4-108)$ & 0.26 \\
\hline PGA, mm & $59(2-100)$ & $56(22-100)$ & 0.59 \\
\hline \multicolumn{4}{|c|}{ Disease activity week $24^{b}$} \\
\hline CDAl & $3.4(0-28.3)$ & $3.5(0-26.6)$ & 0.47 \\
\hline DAS28-CRP & $2.0(1.1-4.8)$ & $2.0(1.0-5.0)$ & 0.82 \\
\hline DAS28-ESR & $2.3(0-6.0)$ & $2.2(0-5.8)$ & 0.91 \\
\hline SJC-66 & $0(0-9)$ & $0(0-7)$ & 0.88 \\
\hline TJC-68 & $1(0-37)$ & $2(0-41)$ & 0.22 \\
\hline CRP, mg/L & $1(0-39)$ & $1(0.1-15)$ & 0.86 \\
\hline $\mathrm{ESR}, \mathrm{mm} / \mathrm{h}$ & $8(1-78)$ & $8(1-48)$ & 0.52 \\
\hline PGA, mm & $11(0-78)$ & $14(0-92)$ & 0.40 \\
\hline
\end{tabular}

$B M I$ body mass index, $R F$ rheumatoid factor, $A C P A$ anti-citrullinated protein antibodies, CDAl clinical disease activity index, DAS28 disease activity score 28 joints, SJC-66 swollen joint count, 66 joints, TJC-68 tender joint count, 68 joints, CRP C-reactive protein, ESR erythrocyte sedimentation rate, PGA patient global assessment

a IFNa positivity defined as IFNa protein level above $136 \mathrm{fg} / \mathrm{mL}$

${ }^{\mathrm{b}}$ Median (range), Mann-Whitney U-test

c $(\%)$, Fisher's exact test

${ }^{d} p<0.05$ after post hoc step-down Bonferroni-Holm correction for multiple testing

Table 3 Factors associated with IFNa positivity at day 1 and week 24

\begin{tabular}{|c|c|c|c|c|}
\hline & OR for IFNa positivity at day $1^{a}$ & $95 \% \mathrm{Cl}$ & OR for IFNa positivity at week $24^{a}$ & $95 \% \mathrm{Cl}$ \\
\hline $\mathrm{RF}+\mathrm{ACPA}+{ }^{\mathrm{b}}$ & 8.92 & $4.21-22.04$ & 5.24 & $2.02-17.95$ \\
\hline Current smoker $^{\mathrm{b}}$ & 1.70 & $0.91-3.15$ & 2.18 & $1.01-4.56$ \\
\hline CDAl day $1^{\mathrm{C}}$ & 1.02 & $1.00-1.04$ & 1.03 & $1.00-1.06$ \\
\hline CRP day $1^{d}$ & 1.00 & $0.99-1.01$ & 1.00 & $0.98-1.01$ \\
\hline
\end{tabular}

Multivariable logistic regression with IFNa positivity at day 1 and week 24 as the dependent variable. At day 1 , IFNa-positive $(\mathrm{n}=91)$ and IFNa-negative $(\mathrm{n}=255)$.

At week 24, IFNa-positive $(n=41)$ and IFNa-negative $(n=305)$

$R F$ rheumatoid factor, $A C P A$ anti-citrullinated protein antibodies, $C D A /$ clinical disease activity index

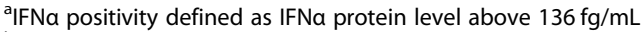

${ }^{\mathrm{b}}$ Yes versus no

'Per point increase

${ }^{\mathrm{d}}$ Per $1 \mathrm{mg} / \mathrm{L}$ increase 
IFNa plasma protein levels decrease to a similar extent in all treatment arms

Next, we investigated the effect of conventional and biologic treatment strategies on IFN $\alpha$ protein levels. IFN $\alpha$ protein levels decreased 24 weeks after treatment initiation in all four treatment arms, and the absolute change in IFN $\alpha$ protein level between day 1 and week 24 did not differ between the treatment arms (Fig. 2A-E).

\section{Baseline IFNa protein levels do not predict remission at week 24}

To evaluate IFN $\alpha$ protein in plasma as a biomarker for remission in early RA, we compared baseline IFN $\alpha$ protein levels in patients who achieved CDAI remission at week 24 versus those with low or moderate/high disease activity. Baseline IFN $\alpha$ protein level did not differ according to remission status in the whole group or in any of the treatment arms (Fig. 3A-E). Similar results were obtained when we compared patients who achieved DAS28-ESR remission to those with low or moderate/ high disease activity (Additional Figure 2A-E).

To ensure that a potential association between IFN $\alpha$ and remission status was not confounded by factors associated with IFN $\alpha$, we added IFN $\alpha$ protein positivity, current smoking, and double-positivity for RF and ACPA to a logistic regression model. After adjustment for current smoking and double-positivity, baseline IFN $\alpha$ protein positivity was still not significantly associated with CDAI (OR 0.79 , 95\% CI $0.47-1.32$ ) or DAS28-ESR (OR 0.64, 95\% CI 0.37-1.09) remission at week 24. In addition, in the 127 patients with IFN $\alpha$ levels above LLOD, the baseline IFN $\alpha$ protein level did not correlate with CDAI or DAS28-ESR at baseline, CDAI or DAS28ESR at week 24, or absolute change in CDAI or DAS28ESR from baseline until week 24 (Additional Figure 3). Thus, the baseline protein level of IFN $\alpha$ did not predict remission 24 weeks after treatment initiation in patients with early RA.

\section{Discussion}

The expression of IRG is upregulated in a subgroup of patients with RA, but IFN $\alpha$ protein levels have not previously been determined in RA. We demonstrate for the first time that IFN $\alpha$ protein positivity is present in a subgroup of patients with untreated early RA. IFN $\alpha$ protein positivity was strongly associated with double-positivity for RF and ACPA but not with disease activity. Treatment with both conventional and biologic DMARDs led to decreased levels of IFN $\alpha$ protein, but the absolute change did not differ between the treatment arms. Pretreatment levels of IFN $\alpha$ protein did not predict remission at week 24 .

Previously, gene variants of interferon regulatory factor-5 (IRF-5) were shown to be associated with seronegative RA [26, 27], leading to the notion that the type I IFN pathway may be more important in autoantibody-negative patients. Here, we show that double-positivity for RF and ACPA is associated with increased risk for IFNa protein positivity, while singlepositivity and double-negativity are related to IFN $\alpha$ negativity. One explanation could be that RF and ACPA in combination might induce a more potent stimulation of IFN $\alpha$ protein production. Indeed, double-positive patients with RA exhibit higher levels of the proinflammatory cytokines TNF, IL-6, and IL- $1 \beta$ than single-positive patients [28]. However, it is also possible that IFN $\alpha$ can induce the production of RF and ACPA. IFN $\alpha$ stimulates $B$ cell activating factor $[29,30]$, plasma cell differentiation, and antibody secretion [31]. Thus, IFN $\alpha$ may stimulate RF and ACPA autoantibody production, which form immune complexes that may in turn stimulate plasmacytoid dendritic cells to produce IFN $\alpha$ protein.

The cut-off for IFN $\alpha$ positivity was $136 \mathrm{fg} / \mathrm{mL}$, based on $3 \mathrm{SD}$ above mean level for 68 healthy blood donors [21]. We obtained similar results when using LLOD as the cut-off. When we measured IFN $\alpha$ protein in 27 healthy controls, all had values below LLOD. Using the same cut-off, $52 \%$ of patients with SLE were IFNopositive [21] compared to $26 \%$ of early RA patients in the present study. This is in line with previous results, where lower IRG expression has been seen in RA compared to SLE [9, 32]. Nucleic acids stimulate IFN $\alpha$ protein production from plasmacytoid dendritic cells, and elevated IFNo protein levels in SLE are associated with the presence of autoantibodies against DNA, ribonucleoprotein, and the RNA-binding Smith antigen [21]. Thus, an explanation for the larger proportion of IFN $\alpha$ positive patients in SLE relative to RA may be that autoantibodies in SLE target endogenous nucleic acids that may be more potent than RF and ACPA in stimulating IFN $\alpha$ protein production. Besides the presence of autoantibodies, SLE and RA share several pathological features including joint pain, fatigue, and a female predisposition, and the diseases may overlap. Therefore, the shared overexpression of IFN $\alpha$ in subgroups of patients with SLE and RA may contribute to the similarities between the diseases. Since the IFN $\alpha / \beta$ receptor inhibitor anifrolumab suggested improvements to primary or secondary outcomes in SLE [33, 34], it will be interesting to see whether RA patients with high IFN $\alpha$ protein level may benefit from this medication.

Increased IRG expression is evident in early and established RA. Although the definition varies, elevated IRG expression was described in $42-61 \%$ of patients with early RA $[10,11]$ and $21-57 \%$ of patients with established RA [9, 11, 12, 35-37]. While its effect on remission is unknown, IRG expression has been associated with disease activity in early RA. Elevated baseline IRG 

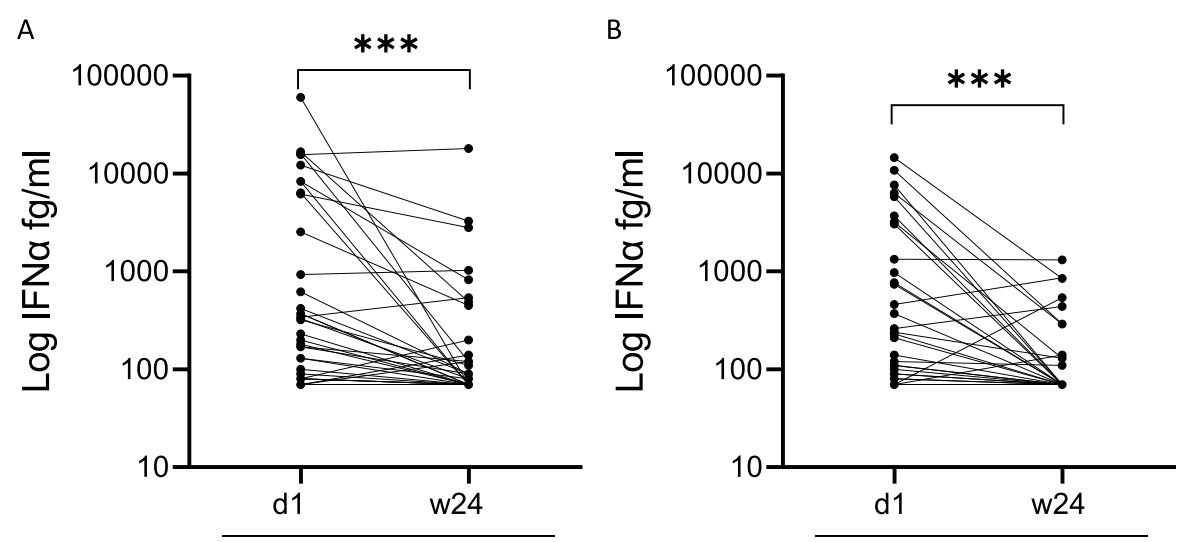

MTX+ prednisone

$\mathrm{MTX}+\mathrm{TNFi}$
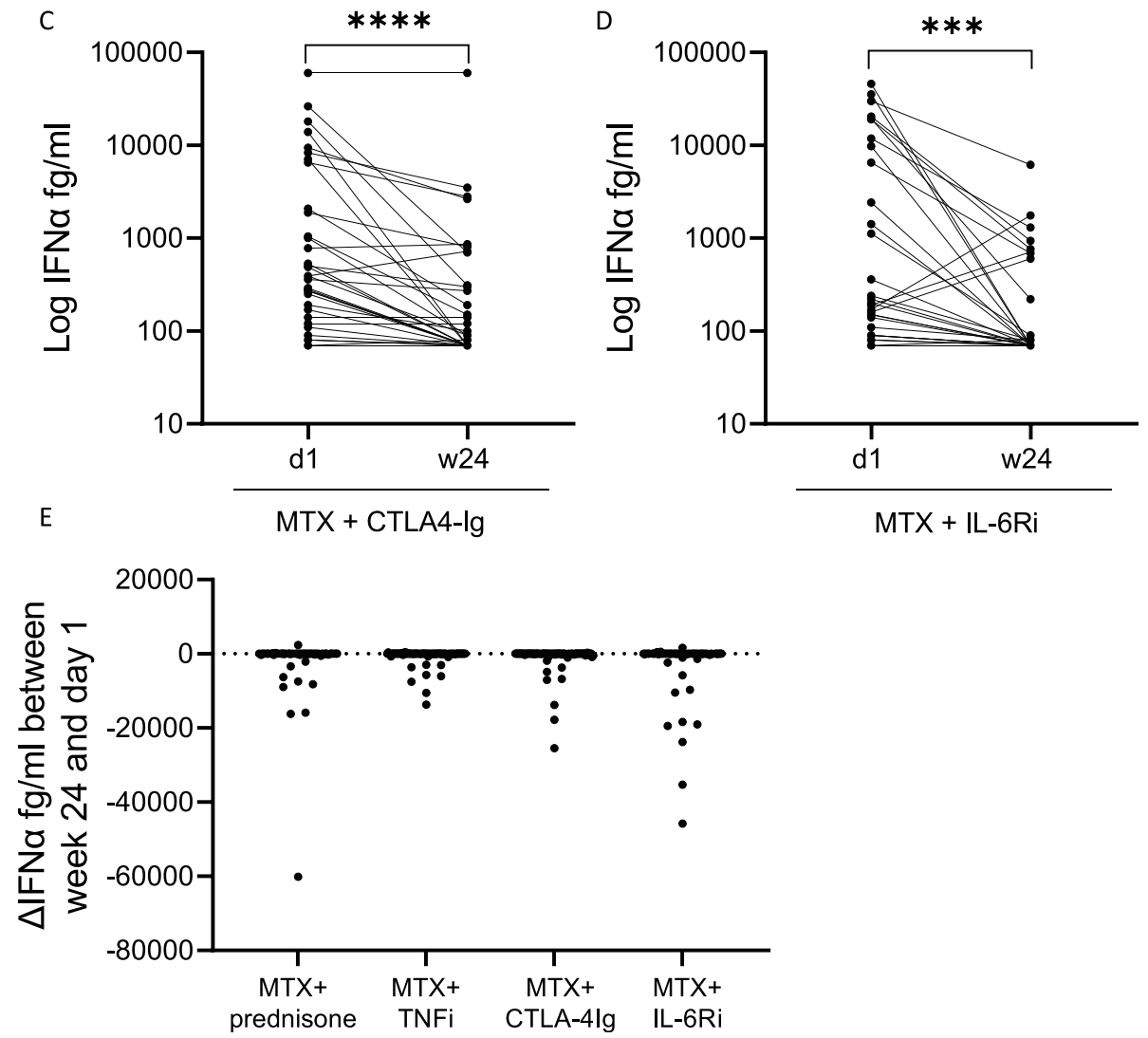

Fig. 2 IFNa protein levels are reduced after treatment initiation with conventional and biologic treatment strategies. IFNa protein levels in plasma from patients with early RA before (d1) and 24 weeks after treatment initiation (w24) with $\mathbf{A}$ methotrexate + prednisone $(\mathrm{n}=85)$, $\mathbf{B}$ methotrexate + TNFi $(n=87)$, C methotrexate + CTLA-4lg $(n=91)$, and $\mathbf{D}$ methotrexate + IL-6Ri $(n=82)$. Wilcoxon matched-pairs signed rank test. $\mathbf{E}$ Absolute difference in IFNa plasma protein levels between week 24 and day 1 in four treatment arms. MTX (methotrexate), TNFi (certolizumab-pegol), CTLA-4lg (abatacept), and IL-6Ri (tocilizumab). Kruskal-Wallis test followed by Dunn's multiple comparison test

expression associated with increased DAS28 6 months after treatment initiation with MTX and glucocorticoid [5] as well as MTX, intramuscular glucocorticoid, and/or hydroxychloroquine [11]. However, another study found no association to disease activity 6 months after treatment initiation with MTX, prednisolone, and/or sulfasalazine [38]. In the present study, IFN $\alpha$ protein positivity was not related to disease activity or remission 6 months after initiation of conventional or biologic treatment.

IRG expression has been suggested as a predictive biomarker for the response to biologic therapies. High or 


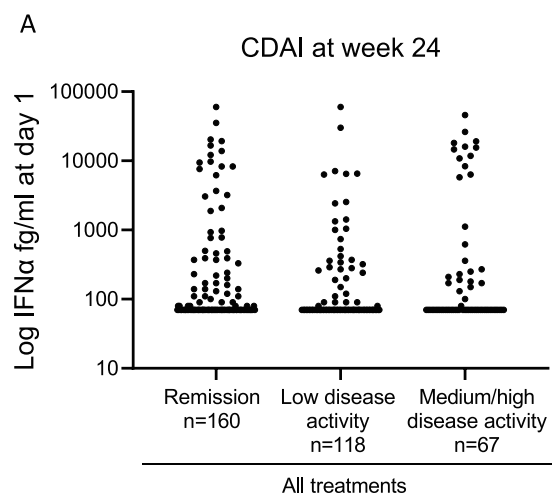

B

CDAl at week 24

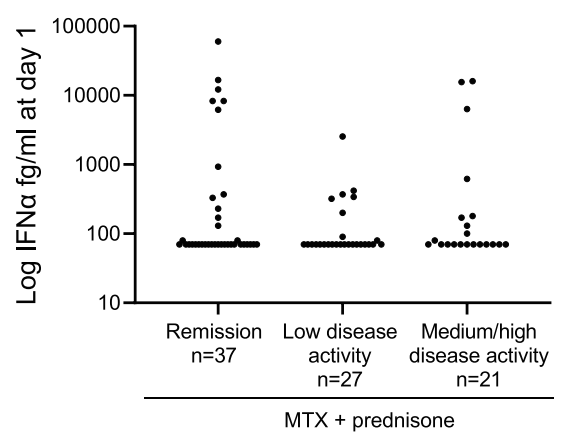

D

CDAl at week 24

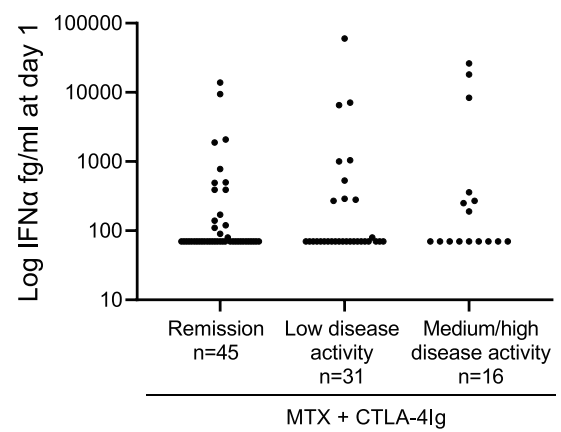

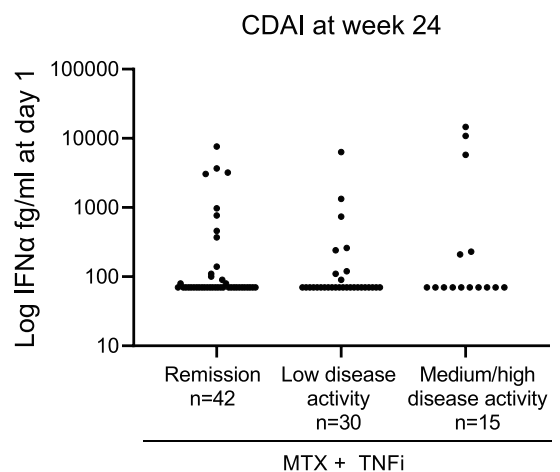

E

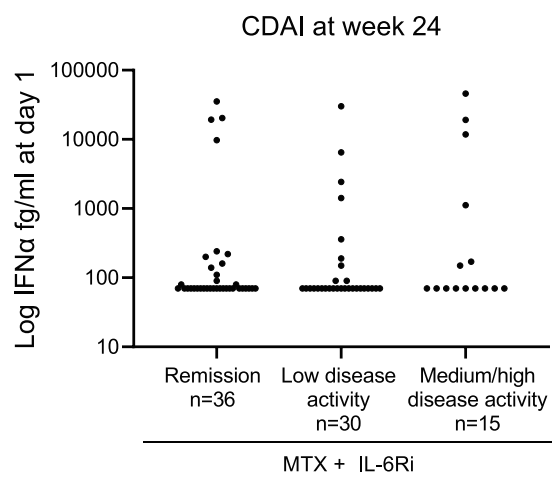

Fig. 3 Baseline IFNa protein levels do not predict remission after treatment. Baseline IFNa protein levels in plasma from patients with early RA, stratified according to CDAl 24 weeks after treatment initiation; in remission (CDAl 0-2.8), low disease activity (CDAl 2.9-10.0), and moderate/high disease activity (CDAl 10.1-76.0) with $\mathbf{A}$ all treatments, B methotrexate + prednisone, $\mathbf{C}$ methotrexate + TNFi, D methotrexate + CTLA-4lg, and $\mathbf{E}$ methotrexate + IL-6Ri. MTX (methotrexate), TNFi (certolizumab-pegol), CTLA-4lg (abatacept), IL-6Ri (tocilizumab). Kruskal-Wallis test followed by Dunn's multiple comparison test

increasing IRG expression associated with poor response to anti-TNF treatment $[12,13]$ although one study reported association with good response [14] and one saw no association [6]. Whether IRG expression predicts response to CTLA-4Ig has not been studied, but high IRG expression was also suggested to predict a good response to anti-IL-6Ri treatment [15]. On a protein level, however, we found that IFN $\alpha$ protein levels decreased irrespective of treatment, and the baseline IFN $\alpha$ protein level did not differ according to remission status in any of the treatment arms. The B-cell depleting agent rituximab was not included as one of the treatment arms, since it is not recommended as the first biological treatment in RA by Swedish or European guidelines. Given the association to autoantibody positivity, it would be of interest to evaluate IFN $\alpha$ protein as a biomarker for treatment effect by rituximab. Indeed, low pre-treatment IRG expression was shown to predict good response to rituximab [16-19]. IFN $\alpha$ stimulates B cell survival, and the repopulation of depleted B-cells may be accelerated 
in patients with high IRG expression. In addition, since IFN $\alpha$ exerts its effect through the JAK-STAT pathway, it is relevant to examine whether IFN $\alpha$ protein level may predict treatment effect to JAK inhibitors in early RA.

This study uses data and plasma samples from the investigator-initiated NORD-STAR study in early untreated RA, and the clinical trial design with randomization to four different treatment arms is a major strength. In addition, previous studies have used proxy markers such as IRG expression to evaluate the role of IFN $\alpha$ in RA, while we were able to sensitively measure the levels of IFN $\alpha$ protein in plasma. However, one limitation is that we do not have data for both IRG expression and IFN $\alpha$ plasma levels. Further, the titers of $\mathrm{RF}$ and ACPA were measured at different laboratories, which precludes the analysis of autoantibody levels in relation to IFN $\alpha$ protein levels.

\section{Conclusions}

In conclusion, IFN $\alpha$ protein positivity was present in a subgroup of patients with early untreated RA and associated with double-positivity for RF and ACPA, but not with disease activity, and did not predict remission 24 weeks after treatment initiation. The association between IFN $\alpha$ and double-positivity for autoantibodies warrants further investigation regarding the role of IFN $\alpha$ in the pathogenesis of early RA. For example, measurement of IFN $\alpha$ protein in synovial fluid would be of value to elucidate the role of IFN $\alpha$ in the local inflammation of the joint.

\begin{abstract}
Abbreviations
ACPA: Anti-citrullinated protein antibodies; ACR: American College of Rheumatology; BMI: Body mass index; CDAl: Clinical disease activity index; CRP: C-reactive protein; CTLA-4lg: Cytotoxic T-lymphocyte-associated molecule-4 immunoglobulin; DAS28: Disease activity score, 28 joints; DMAR D: Disease-modifying anti-rheumatic drug; ESR: Erythrocyte sedimentation rate; EULAR: European League Against Rheumatism; IFN: Interferon; IL6Ri: Interleukin-6 receptor inhibitors; IRF: Interferon regulatory factor; IRG: Type I IFN responsive genes; LLOD: Lowest limit of detection; MTX: Methotrexate; NORD-STAR: Nordic rheumatic diseases strategy trials and registries; PGA: Patient global assessment; RA: Rheumatoid arthritis; RF: Rheumatoid factor; Simoa: Single molecular array; SJC-66: Swollen joint count in 66 joints; SLE: Systemic lupus erythematosus; TJC-68: Tender joint count in 68 joints; TNFi: Tumor necrosis factor inhibitors
\end{abstract}

\section{Supplementary Information}

The online version contains supplementary material available at https://doi. org/10.1186/s13075-021-02556-1.

Additional file 1:. Figure S1. IFNa protein positivity is associated with double-positivity for RF and ACPA. RF/ACPA status in patients who are IFNa positive and IFNa negative at baseline.

Additional file 2:. Figure S2. Baseline IFNa protein levels do not predict remission in any of the treatment arms. Baseline IFNa protein levels in plasma from patients with early RA stratified according to DAS28-ESR 24 weeks after treatment initiation; in remission (DAS28-ESR $<2.6$ ), low disease activity $(2.6<$ DAS28-ESR $\leq 3.2)$ or moderate/high disease activity (DAS28-ESR > 3.2) with A) all treatments, B) methotrexate + prednisone,
C) methotrexate + TNFi, D) methotrexate + (TLA-4lg and E) methotrexate + IL-6Ri. MTX (methotrexate), TNFi (certolizumab-pegol), CTLA-4Ig (abatacept), IL-6Ri (tocilizumab). Kruskal-Wallis test followed by Dunn's multiple comparison test.

Additional file 3:. Figure S3. IFNa protein levels at baseline do not correlate with CDAI or DAS28-ESR. Correlation between IFNa protein level in patients with levels above detection limit at day 1 and A) CDAl day 1 , B) CDAl week 24, C) absolute difference in CDAl between week 24 and day 1, D) DAS28-ESR day 1, E) DAS28-ESR week 24 and F) absolute difference in DAS28-ESR between week 24 and day 1. Spearman rank correlation coefficient

Additional file 4:. Table S1 Demographic and clinical characteristics of patients with IFNa below or above lowest limit of detection

\section{Acknowledgements}

We thank all the patients, investigators, nurses, joint assessors, and study teams involved in the NORD-STAR study. We also thank Simon Krabbe for data processing, Thomas Karlsson at Akademistatistik at Gothenburg University for the statistical support, and Anna Pfister and Irina Nilsson for the technical help with the Simoa analyses.

\section{Authors' contributions}

MS: data interpretation and analysis, manuscript drafting, review, and editing. ACL: methodology, review, and editing. MLH, MØ, MSH, TU, EAH, MTN, JL, $\mathrm{DN}, \mathrm{KHP}, \mathrm{BG}, \mathrm{GG}$, and RV: project administration, review, and editing. JA and KA: laboratory analysis, review, and editing. KB and HZ: methodology, review, and editing. AR: conceptualization, project administration, data interpretation and analysis, review, and editing. The authors read and approved the final manuscript.

\section{Funding}

AR is supported by the Swedish Research Council (\#2019-01035); the Swedish state under the agreement between the Swedish government and the country councils, the ALF-agreement (\#ALFGBG-717541); and King Gustaf V's 80-year foundation (\#FAl-2019-0603). MS is supported by the Gothenburg Society of Medicine (\#GLS-935039). DN is supported by The Academy of Finland, Finska Läkaresällskapet, and Institutional grant of Helsinki University Hospital. KB is supported by the Swedish Research Council (\#2017-00915); the Alzheimer Drug Discovery Foundation (ADDF), USA (\#RDAPB-2018092016615); the Swedish Alzheimer Foundation (\#AF-742881); Hjärnfonden, Sweden (\#FO2017-0243); the Swedish state under the agreement between the Swedish government and the County Councils, the ALF-agreement (\#ALFGBG-715986); the European Union Joint Program for Neurodegenerative Disorders (\#JPND2019-466-236); and the National Institute of Health (NIH), USA (grant \#1R01AG068398-01). HZ is a Wallenberg Scholar supported by grants from the Swedish Research Council (\#2018-02532); the European Research Council (\#681712); Swedish State Support for Clinical Research (\#ALFGBG-720931); the Alzheimer Drug Discovery Foundation (ADDF), USA (\#201809-2016862); the AD Strategic Fund and the Alzheimer's Association (\#ADSF-21-831376-C, \#ADSF-21-831381-C, and \#ADSF-21-831377-C); the Olav Thon Foundation, the Erling-Persson Family Foundation, Stiftelsen för Gamla Tjänarinnor, Hjärnfonden, Sweden (\#FO2019-0228); and the European Union's Horizon 2020 research and innovation program under the Marie SkłodowskaCurie grant agreement No 860197 (MIRIADE) and the UK Dementia Research Institute at UCL. Open access funding is provided by the Gothenburg University library.

Availability of data and materials

All data relevant to the study is included in the article or uploaded as supplementary information. Data are available upon reasonable request.

\section{Declarations}

Ethics approval and consent to participate

All participants signed a written informed consent and the study was approved by the regional ethics board in Stockholm (d.nr. 2011/2069-31/4 and amendment 2019-05705).

Consent for publication Not applicable. 


\section{Competing interests}

MS, ACL, TU, MTN, JL, KHP, GG, JA, KA, and AR have no competing interests to declare. MLH has received research grants from Abbvie, Biogen, BMS, Celltrion, Eli-Lilly, Janssen Biologics B.V, Lundbeck Fonden, MSD, Pfizer, Roche, Samsung Bioepis, Sandoz, and Novartis; chairs the steering committee of the Danish Rheumatology Quality Registry (DANBIO), which receives public funding from the hospital owners and funding from pharmaceutical companies; and co-chairs EuroSpA, which generates real-world evidence of treatment of psoriatic arthritis and axial spondyloarthritis based on secondary data and is partly funded by Novartis. M $\varnothing$ has received research grants from Abbvie, BMS, Merck, Celgene, and Novartis, and speaker and/or consulting fees from Abbvie, BMS, Boehringer-Ingelheim, Celgene, Eli-Lilly, Hospira, Janssen, Merck, Novartis, Novo, Orion, Pfizer, Regeneron, Roche, Sandoz, Sanofi, and UCB. MSH has received speaker's honoraria from Lilly and Roche over the last 4 years outside the submitted work. EAH has received grants from the Norwegian Regional Health Authorities and The South-Eastern Norway Regional Health Authority during the conduct of the NORD-STAR study, and speaker and/or consulting fees from Pfizer, AbbVie, Celgene, Novartis, Janssen, Gilead, Eli-Lilly, and UCB outside the submitted work. DN has received consulting fees from AbbVie, BMS, MSD, Novartis, Pfizer, Roche, and UCB. BG has received speaking fees from Amgen and Novartis. KB has served as a consultant, at advisory boards or at data monitoring committees for Abcam, Axon, Biogen and JOMDD/Shimadzu, Julius Clinical, Lilly, MagQu, Novartis, Roche Diagnostics, and Siemens Healthineers and is a co-founder of Brain Biomarker Solutions in Gothenburg AB (BBS), which is a part of the GU Ventures Incubator Program (outside the submitted work). HZ has served at scientific advisory boards for Eisai, Denali, Roche Diagnostics, Wave, Samumed, Siemens Healthineers, Pinteon Therapeutics, Nervgen, AZTherapies, and CogRx; has given lectures in symposia sponsored by Cellectricon, Fujirebio, Alzecure, and Biogen; and is a co-founder of Brain Biomarker Solutions in Gothenburg AB (BBS), which is a part of the GU Ventures Incubator Program (outside submitted work). RV has received research and educational support (grants) from BMS, GSK, Lilly, Pfizer, Roche, and UCB and consultancy and/or speaking fees from AbbVie, AstraZeneca, Biogen, Biotest, BMS, Galapagos, Gilead, GSK, Janssen, Pfizer, Sanofi, Servier, UCB, and Vielabio.

\section{Author details}

${ }^{1}$ Department of Rheumatology and Inflammation Research, Institute of Medicine, Sahlgrenska Academy at the University of Gothenburg, Guldhedsgatan 10A, S-405 30 Gothenburg, Sweden. 'Rheumatology Clinic, Sahlgrenska University Hospital, Gothenburg, Sweden. ${ }^{3}$ Copenhagen Center for Arthritis Research, Center for Rheumatology and Spine Diseases, Rigshospitalet, Glostrup, Denmark. ${ }^{4}$ Department of Clinical Medicine, Faculty of Health and Medical Sciences, University of Copenhagen, Copenhagen, Denmark. ${ }^{5}$ Division of Rheumatology and Research, Diakonhjemmet Hospital, Oslo, Norway. ${ }^{6}$ Institute of Clinical Medicine, University of Oslo, Oslo, Norway. ${ }^{7}$ Amsterdam Rheumatology and Immunology Center, Reade, Amsterdam, The Netherlands. ${ }^{8}$ Department of Rheumatology and Amsterdam Rheumatology Center, Amsterdam University Medical Centres, Amsterdam, The Netherlands. ${ }^{9}$ Department of Medicine, Rheumatology Unit, Center for Molecular Medicine (CMM), Karolinska Institute, Karolinska University Hospital, Stockholm, Sweden. ${ }^{10}$ Department of Medicine and Rheumatology, Helsinki University and University Hospital, Helsinki, Finland. "'Danish Hospital for Rheumatic Diseases, University Hospital of Southern Denmark, Sønderborg, Denmark. ${ }^{12}$ Department of Regional Health Research, University of Southern Denmark, Odense, Denmark. ${ }^{13}$ Centre for Rheumatology Research, Landspitali University Hospital, Reykjavik, Iceland. ${ }^{14}$ Faculty of Medicine, University of Iceland, Reykjavik, Iceland. ${ }^{15}$ Department of Psychiatry and Neurochemistry, Institute of Neuroscience and Physiology, Sahlgrenska Academy at the University of Gothenburg, Gothenburg, Sweden. ${ }^{16} \mathrm{Clinical}$ Neurochemistry Laboratory, Sahlgrenska University Hospital, Mölndal, Sweden. ${ }^{17}$ UK Dementia Research Institute at UCL, London, UK. ${ }^{18}$ Department of Neurodegenerative Disease, UCL Institute of Neurology, London, UK.

Received: 26 April 2021 Accepted: 15 June 2021

Published online: 13 July 2021

\section{References}

1. Sugiyama D, Nishimura K, Tamaki K, Tsuji G, Nakazawa T, Morinobu A, et al. Impact of smoking as a risk factor for developing rheumatoid arthritis: a meta-analysis of observational studies. Ann Rheum Dis. 2010;69(1):70-81. https://doi.org/10.1136/ard.2008.096487.

2. Han SW, Lee WK, Kwon KT, Lee BK, Nam EJ, Kim GW. Association of polymorphisms in interferon regulatory factor 5 gene with rheumatoid arthritis: a metaanalysis. J Rheumatol. 2009;36(4):693-7. https://doi.org/10.3 899/jheum.081054.

3. Remmers EF, Plenge RM, Lee AT, Graham RR, Hom G, Behrens TW, et al. STAT4 and the risk of rheumatoid arthritis and systemic lupus erythematosus. N Engl J Med. 2007;357(10):977-86. https://doi.org/10.1056/ NEJMoa073003.

4. Castañeda-Delgado JE, Bastián-Hernandez Y, Macias-Segura N, SantiagoAlgarra D, Castillo-Ortiz JD, Alemán-Navarro AL, et al. Type I interferon gene response is increased in early and established rheumatoid arthritis and correlates with autoantibody production. Front Immunol. 2017;8:285.

5. Rodríguez-Carrio J, Alperi-López M, López P, Ballina-García FJ, Suárez A. Heterogeneity of the type I interferon signature in rheumatoid arthritis: a potential limitation for its use as a clinical biomarker. Front Immunol. 2018;8: 2007. https://doi.org/10.3389/fimmu.2017.02007.

6. Cantaert T, van Baarsen LG, Wijbrandts CA, Thurlings RM, van de Sande MG, Bos C, et al. Type I interferons have no major influence on humoral autoimmunity in rheumatoid arthritis. Rheumatology. 2010;49(1):156-66. https://doi.org/10.1093/rheumatology/kep345.

7. de Jong TD, Blits M, de Ridder S, Vosslamber S, Wolbink G, Nurmohamed MT, et al. Type I interferon response gene expression in established rheumatoid arthritis is not associated with clinical parameters. Arthritis Res Ther. 2016;18(1):290. https://doi.org/10.1186/s13075-016-1191-y.

8. McNab F, Mayer-Barber K, Sher A, Wack A, O'Garra A. Type I interferons in infectious disease. Nature Reviews Immunology. 2015;15(2):87-103. https:// doi.org/10.1038/nri3787.

9. Higgs BW, Liu Z, White B, Zhu W, White WI, Morehouse C, et al. Patients with systemic lupus erythematosus, myositis, rheumatoid arthritis and scleroderma share activation of a common type I interferon pathway. Ann Rheum Dis. 2011;70(11):2029-36. https://doi.org/10.1136/ard.2011.150326.

10. Lübbers J, Brink M, van de Stadt LA, Vosslamber S, Wesseling JG, van Schaardenburg D, et al. The type I IFN signature as a biomarker of preclinical rheumatoid arthritis. Ann Rheum Dis. 2013;72(5):776-80. https:// doi.org/10.1136/annrheumdis-2012-202753.

11. Cooles FAH, Anderson AE, Lendrem DW, Norris J, Pratt AG, Hilkens CMU, et al. The interferon gene signature is increased in patients with early treatment-naive rheumatoid arthritis and predicts a poorer response to initial therapy. J Allergy Clin Immunol. 2018;141(1):445-8.e4.

12. Sekiguchi N, Kawauchi S, Furuya T, Inaba N, Matsuda K, Ando S, et al. Messenger ribonucleic acid expression profile in peripheral blood cells from RA patients following treatment with an anti-TNF-alpha monoclonal antibody, infliximab. Rheumatology. 2008;47(6):780-8. https://doi.org/10.1 093/rheumatology/ken083.

13. van Baarsen $L G$, Wijbrandts $C A$, Rustenburg F, Cantaert T, van der Pouw Kraan TC, Baeten DL, et al. Regulation of IFN response gene activity during infliximab treatment in rheumatoid arthritis is associated with clinical response to treatment. Arthritis Res Ther. 2010;12(1):R11.

14. Wright HL, Thomas HB, Moots RJ, Edwards SW. Interferon gene expression signature in rheumatoid arthritis neutrophils correlates with a good response to TNFi therapy. Rheumatology. 2015;54(1):188-93. https://doi. org/10.1093/rheumatology/keu299.

15. Sanayama Y, Ikeda K, Saito Y, Kagami S-I, Yamagata M, Furuta S, et al. Prediction of therapeutic responses to tocilizumab in patients with rheumatoid arthritis: biomarkers identified by analysis of gene expression in peripheral blood mononuclear cells using genome-wide DNA microarray. Arthritis \& Rheumatology. 2014;66(6):1421-31. https://doi.org/10.1002/art.38400.

16. de Jong TD, Sellam J, Agca R, Vosslamber S, Witte BI, Tsang ASM, et al. A multi-parameter response prediction model for rituximab in rheumatoid arthritis. Joint Bone Spine. 2018;85(2):219-26. https://doi.org/10.1016/j. jbspin.2017.02.015.

17. Raterman $H G$, Vosslamber $S$, de Ridder $S$, Nurmohamed MT, Lems WF, Boers $M$, et al. The interferon type I signature towards prediction of non-response to rituximab in rheumatoid arthritis patients. Arthritis Res Ther. 2012;14(2): R95. https://doi.org/10.1186/ar3819.

18. de Jong TD, Vosslamber S, Blits M, Wolbink G, Nurmohamed MT, van der Laken CJ, et al. Effect of prednisone on type I interferon signature in rheumatoid arthritis: consequences for response prediction to rituximab. Arthritis Res Ther. 2015;17(1):78. https://doi.org/10.1186/s13075-015-0564-y. 
19. Vosslamber S, Raterman HG, van der Pouw Kraan TC, Schreurs MW, von Blomberg BM, Nurmohamed MT, et al. Pharmacological induction of interferon type I activity following treatment with rituximab determines clinical response in rheumatoid arthritis. Ann Rheum Dis. 2011;70(6):1153-9. https://doi.org/10.1136/ard.2010.147199.

20. Llibre A, Bondet V, Rodero MP, Hunt D, Crow YJ, Duffy D. Development and validation of an ultrasensitive single molecule array digital enzyme-linked immunosorbent assay for human interferon-alpha. J Vis Exp. 2018;136.

21. Mathian A, Mouries-Martin S, Dorgham K, Devilliers H, Yssel H, Garrido Castillo $L$, et al. Ultrasensitive serum interferon-a quantification during SLE remission identifies patients at risk for relapse. Ann Rheum Dis. 2019;78(12): 1669-76. https://doi.org/10.1136/annrheumdis-2019-215571.

22. Smolen JS, Landewé RBM, Bijlsma JWJ, Burmester GR, Dougados M, Kerschbaumer A, et al. EULAR recommendations for the management of rheumatoid arthritis with synthetic and biological disease-modifying antirheumatic drugs: 2019 update. Ann Rheum Dis. 2020;79(6):685-99. https://doi.org/10.1136/annrheumdis-2019-216655.

23. Singh JA, Saag KG, Bridges SL Jr, Akl EA, Bannuru RR, Sullivan MC, et al. 2015 American College of Rheumatology guideline for the treatment of rheumatoid arthritis. Arthritis Care Res. 2016;68(1):1-25. https://doi.org/10.1 002/acr.22783.

24. Hetland ML, Haavardsholm EA, Rudin A, Nordström D, Nurmohamed M, Gudbjornsson B, et al. Active conventional treatment and three different biological treatments in early rheumatoid arthritis: phase IV investigator initiated, randomised, observer blinded clinical trial. BMJ. 2020;371:m4328.

25. Glinatsi D, Heiberg MS, Rudin A, Nordstrom D, Haavardsholm EA, Gudbjornsson B, et al. Head-to-head comparison of aggressive conventional therapy and three biological treatments and comparison of two deescalation strategies in patients who respond to treatment: study protocol for a multicenter, randomized, open-label, blinded-assessor, phase 4 study. Trials. 2017;18(1):161. https://doi.org/10.1186/s13063-017-1891-X.

26. Wang C, Kokkonen H, Sandling JK, Johansson M, Seddighzadeh M, Padyukov $L$, et al. Preferential association of interferon regulatory factor 5 gene variants with seronegative rheumatoid arthritis in 2 Swedish casecontrol studies. The Journal of Rheumatology. 2011;38(10):2130-2. https:// doi.org/10.3899/jrheum.110322.

27. Sigurdsson S, Padyukov L, Kurreeman FAS, Liljedahl U, Wiman A-C, Alfredsson $L$, et al. Association of a haplotype in the promoter region of the interferon regulatory factor 5 gene with rheumatoid arthritis. Arthritis Rheum. 2007:56(7):2202-10. https://doi.org/10.1002/art.22704.

28. Sokolove J, Johnson DS, Lahey LJ, Wagner CA, Cheng D, Thiele GM, et al. Rheumatoid factor as a potentiator of anti-citrullinated protein antibodymediated inflammation in rheumatoid arthritis. Arthritis \& rheumatology. 2014;66(4):813-21. https://doi.org/10.1002/art.38307.

29. Ittah M, Miceli-Richard C, Eric Gottenberg J, Lavie F, Lazure T, Ba N, et al. B cell-activating factor of the tumor necrosis factor family (BAFF) is expressed under stimulation by interferon in salivary gland epithelial cells in primary Sjögren's syndrome. Arthritis Res Ther. 2006;8(2):R51. https://doi.org/10.11 86/ar1912.

30. Lundell A-C, Nordström I, Andersson K, Lundqvist C, Telemo E, Nava S, et al. IFN type I and II induce BAFF secretion from human decidual stromal cells. Sci Rep. 2017;7:39904.

31. Jego G, Palucka AK, Blanck JP, Chalouni C, Pascual V, Banchereau J. Plasmacytoid dendritic cells induce plasma cell differentiation through type I interferon and interleukin 6. Immunity. 2003;19(2):225-34. https://doi.org/1 0.1016/S1074-7613(03)00208-5.

32. Hua J, Kirou K, Lee C, Crow MK. Functional assay of type I interferon in systemic lupus erythematosus plasma and association with anti-RNA binding protein autoantibodies. Arthritis Rheum. 2006;54(6):1906-16. https:// doi.org/10.1002/art.21890.

33. Furie RA, Morand EF, Bruce IN, Manzi S, Kalunian KC, Vital EM, et al. Type I interferon inhibitor anifrolumab in active systemic lupus erythematosus (TULIP-1): a randomised, controlled, phase 3 trial. The Lancet Rheumatology. 2019;1(4):e208-e19. https://doi.org/10.1016/\$2665-9913(19)30076-1.

34. Morand EF, Furie R, Tanaka Y, Bruce IN, Askanase AD, Richez C, et al. Trial of anifrolumab in active systemic lupus erythematosus. N Engl J Med. 2020; 382(3):211-21. https://doi.org/10.1056/NEJMoa1912196.

35. Reynier F, Petit F, Paye M, Turrel-Davin F, Imbert PE, Hot A, et al. Importance of correlation between gene expression levels: application to the type I interferon signature in rheumatoid arthritis. PLoS One. 2011;6(10):e24828. https://doi.org/10.1371/journal.pone.0024828.
36. Mavragani CP, La DT, Stohl W, Crow MK. Association of the response to tumor necrosis factor antagonists with plasma type I interferon activity and interferon-beta/alpha ratios in rheumatoid arthritis patients: a post hoc analysis of a predominantly Hispanic cohort. Arthritis Rheum. 2010;62(2): 392-401. https://doi.org/10.1002/art.27226.

37. van der Pouw Kraan TC, Wijbrandts CA, van Baarsen LG, Voskuyl AE, Rustenburg F, Baggen JM, et al. Rheumatoid arthritis subtypes identified by genomic profiling of peripheral blood cells: assignment of a type I interferon signature in a subpopulation of patients. Ann Rheum Dis. 2007; 66(8):1008-14. https://doi.org/10.1136/ard.2006.063412.

38. de Jong TD, Snoek T, Mantel E, van der Laken CJ, van Vollenhoven RF, Lems WF. Dynamics of the type I interferon response during immunosuppressive therapy in rheumatoid arthritis. Front Immunol. 2019;10:902.

\section{Publisher's Note}

Springer Nature remains neutral with regard to jurisdictional claims in published maps and institutional affiliations.

\section{Ready to submit your research? Choose BMC and benefit from:}

- fast, convenient online submission

- thorough peer review by experienced researchers in your field

- rapid publication on acceptance

- support for research data, including large and complex data types

- gold Open Access which fosters wider collaboration and increased citations

- maximum visibility for your research: over $100 \mathrm{M}$ website views per year

At BMC, research is always in progress.

Learn more biomedcentral.com/submissions 